\title{
Layanan informasi untuk meningkatkan pemahaman penyalahgunaan narkoba pada siswa
}

\author{
Ryan Rizki Luthfiansyah ${ }^{1 *}$, Miskanik Miskanik ${ }^{2)}$, Hamam Hamam ${ }^{3)}$ \\ 1,2,3) Universitas Indraprasta PGRI \\ *) ryanrizkiluthfiansyah@gmail.com
}

\begin{abstract}
Article History: Received: 03/08/2021; Revised: 19/10/2021; Accepted: 22/10/2021 Published: 30/10/2021.
\end{abstract}

How to cite: Luthfiansyah, R.R., Miskanik M., \& Hamam, H. (2021) Layanan informasi untuk meningkatkan pemahaman penyalahgunaan narkoba pada siswa. Orien: Cakrawala Ilmiah Mahasiswa, 1(2), pp. 135-142. DOI: 10.30998/ocim.v1i2.4886

This is an open access article

distributed under the Creative Commons 4.0 Attribution License, which permits unrestricted use, distribution, and reproduction in any medium, provided the original work is properly cited. (c) 2021, Luthfiansyah, Miskanik, \& Hamam.

\begin{abstract}
Abstrak: penelitian ini bertujuan untuk meningkatkan pemahaman penyalahgunaan narkoba pada remaja dalam hal ini khususnya siswa SMK kelas X SMK Trisastra 1 Jakarta. Penelitian ini merupakan penelitian kuantitatif dengan menggunakan pendekatan eksperimen. Desain penelitian eksperimen yang digunakan adalah one group pretest posttest design. Sampel penelitian ini adalah 38 siswa yang ditarik dari simple random sampling. Data dikumpulkan dari instrumen angket. Hasil pretest menunjukkan hasil rata-rata persentase sebesar $49.50 \%$ yang termasuk dalam kategori sedang dan hasil posttest menunjukkan peningkatan yaitu sebesar $91.41 \%$ yang termasuk dalam kategori sangat tinggi. Peningkatan pemahaman siswa tentang bahaya penyalahgunaan narkoba yang lebih spesifik ditunjukkan dari hasil perhitungan uji beda dengan rumus t-test yang menunjukkan thitung 22.781 dan tabel 3.576 jadi nilai thitung $>t_{\text {tabel }}$ sehingga dapat dikatakan bahwa terdapat pengaruh layanan informasi pada pemahaman siswa tentang penyalahgunaan narkoba.
\end{abstract}

Kata Kunci: layanan informasi, pemahaman penyalahgunaan narkoba

Abstract: this study aims to improve the understanding of drug abuse in adolescents, in this case, especially students of class X SMK Trisastra 1 Jakarta. This research is a quantitative research using an experimental approach. The experimental research design used was one group pre-test posttest design. The sample of this study was 38 students drawn from simple random sampling. Data were collected from a questionnaire instrument. The results of the pre test showed an average percentage of $49.50 \%$ which was included in the medium category and the post test results showed an increase of $91.41 \%$ which was included in the very high category. Increased understanding of students about the dangers of drug abuse that is more specific is shown from the results of the different test calculations with the t-test formula which shows thitung 22,781 and tabel 3,576 so the value of $t_{\text {hitung }}>t_{\text {tabel }}$. Result shown that information service has significant effect to students understanding about drug abuse.

Keywords: information service, drug abuse

\section{Pendahuluan}

Generasi muda merupakan sebuah aset negara sebagai calon pemimpin di masa depan yang akan mewujudkan cita-cita Negara Kesatuan Republik Indonesia. Namun sangat ironis, jika generasi muda yang menjadi tumpuan harapan sebagai calon pemimpin bangsa harus terjatuh ke dalam jurang gelap narkoba. Ya, salah satu penyalahguna terbesar yang menjadi sorotan di 
Indonesia adalah individu dengan kisaran umur 15-35 tahun dan dapat dikatakan rentang umur tersebut adalah kriteria yang cocok diklasifikasikan sebagai generasi millennial penerus bangsa.

Angka penyalahgunaan narkoba yang di kalangan remaja telah menunjukkan angka yang mengkhawatirkan. Jika generasi milenial sudah menjadi penyalahguna narkoba maka bukan tidak mungkin mereka rentan menjadi penyalah guna jangka panjang. Selain itu World Drugs Report 2018 yang diterbitkan United Nations Office on Drugs and Crime (UNODC), menyebutkan sebanyak 275 juta penduduk di dunia atau 5,6\% dari penduduk dunia dengan rentang usia 1564 tahun pernah mengonsumsi narkoba. Sementara di NKRI, BNN focal point di bidang Pencegahan dan Pemberantasan Penyalahgunaan dan Peredaran Gelap Narkoba (P4GN) mengantongi angka penyalahgunaan narkoba tahun 2017 sebanyak 3.376 .115 orang pada rentang usia 10-59 tahun. Dengan angka tersebut, dapat dikatakan Indonesia memiliki situasi “Darurat Narkoba".

Untuk itu BNN sebagai leading sector dalam upaya pemberantasan penyalahgunaan narkoba, terus menjalin kerja sama yang solid dengan Polri, TNI, Bea Cukai, Imigrasi, Pemerintah Daerah dan instansi terkait lainnya serta seluruh komponen masyarakat terus menggalakkan berbagai penyuluhan terkait dengan efek negatif yang akan muncul pada individu yang menjadi penyalah guna narkoba dengan harapan menekan angka penyalah guna di lingkungan masyarakat dan menyeluruh di seluruh wilayah Indonesia.

Berdasarkan uraian di atas telah diketahui bahwa peredaran dan dampak narkoba saat ini sudah menimbulkan keresahan bagi seluruh lapisan masyarakat. Selain menyebabkan efek ketergantungan atau kecanduan terhadap penyalah guna, narkoba juga memberikan efek yang buruk bagi kesehatan si penyalah guna. Salah satu efek negatif yang ditimbulkan adalah rasa dehidrasi dalam tubuh. Penyalahgunaan narkoba akan menyebabkan ketidakseimbangan elektrolit dalam tubuh dan akan menyebabkan tubuh kekurangan cairan. Jika hal ini terus terjadi, maka akan menyebabkan tubuh kejang-kejang, munculnya halusinasi, perilaku lebih agresif, dan rasa sesak pada bagian dada. Yang terburuk, efek jangka panjang yang akan ditimbulkan dari dehidrasi ini adalah kerusakan pada otak si penyalah guna.

Halusinasi menjadi salah satu efek yang paling sering dialami oleh penyalahguna narkoba seperti ganja yang merupakan jenis narkotika golongan I. Tak hanya itu, jika penyalah guna mengonsumsi dalam dosis tinggi akan memicu terjadinya muntah, mual, rasa takut yang berlebih, serta gangguan kecemasan. Dalam pemakaian yang lebih lama, penyalah guna akan memunculkan dampak yang lebih buruk bagi kesehatannya berupa gangguan mental, depresi, serta rasa cemas yang terjadi secara terus-menerus.

Dampak terburuk bagi penyalah guna narkoba dalam dosis tinggi adalah kematian. Kejadian ini dikenal di seluruh lapisan masyarakat dengan kata overdosis. Efek ini biasa ditemukan pada penyalah guna jenis narkoba golongan I seperti sabu-sabu, opium, dan kokain yang memicu tubuh mengalami kejang-kejang dan jika hal ini dibiarkan akan menyebabkan kematian. Nyawa menjadi taruhan nyata yang harus siap diterima oleh penyalah guna narkoba dan tentunya akan merugikan diri sendiri dan orang-orang terkasih yang ditinggalkan.

Selain berdampak buruk pada kondisi kesehatan si penyalah guna, narkoba juga memiliki dampak buruk terhadap kualitas hidup penyalah guna. Mengonsumsi narkoba akan menimbulkan pikiran, mental, dan kualitas hidup yang terganggu. Gangguan kualitas hidup biasanya ditandai dengan sulitnya penyalah guna dalam berkonsentrasi saat bekerja, mengalami masalah keuangan karena penyalah guna rela menghabiskan hartanya tanpa berpikir dua kali untuk membeli barang haram tersebut (hal ini biasa terjadi saat penyalah guna mengalami fase kecanduan), serta penyalah guna akan berhadapan dengan aparat penegak hukum yaitu kepolisian jika terbukti melanggar hukum. 
Pada Pasal 1 Undang-Undang Nomor 35 Tahun 2009 tentang Narkotika dijelaskan bahwa Narkotika adalah zat atau obat yang berasal dari tanaman atau bukan tanaman, baik sintetis maupun semisintetis, yang dapat menyebabkan penurunan atau perubahan kesadaran, hilangnya rasa, mengurangi sampai menghilangkan rasa nyeri, dan dapat menimbulkan ketergantungan, yang dibedakan ke dalam golongan-golongan sebagaimama terlampir dalam Undang-Undang ini.

Narkoba mempunyai banyak macam, bentuk, warna, dan pengaruhnya terhadap tubuh. Yang menjadi tanda tanya besar adalah mengapa banyak penyalah guna narkoba yang sulit melepaskan cengkraman eratnya dari barang haram tersebut? Jackobus (dalam Rohman, 2019), mengemukakan bahwa narkoba memiliki sifat atau daya adiksi (ketagihan) yang akan dialami pula oleh penyalah guna setelah mengonsumsi narkoba. Selain itu narkoba mempunyai daya toleran (penyesuaian) yang tinggi. Dapat diartikan bahwa, zat atau obat (narkoba) yang dikonsumsi oleh penyalah guna akan sangat cepat bereaksi dengan memberikan efek halusinasi yang dapat membuat penyalah guna menjadi sangat rileks. Yang terakhir adalah daya habitual (kebiasaan). Penyalah guna akan menganggap bahwa mengonsumsi narkoba sudah merupakan hal yang biasa dan tidak bahkan ia akan sangat membutuhkan narkoba pada momen-momen tertentu dalam kehidupannya misalnya saat sedih, galau, resah dan sebagainya.

Guru Bimbingan dan Konseling (BK) memiliki tanggung jawab moral untuk memberikan sebuah edukasi dan informasi yang berharga terkait dengan penyalahgunaan narkoba kepada siswa. Hal ini dapat berupa pemberian layanan informasi yang dimaksudkan sebagai upaya preventif/pencegahan terhadap penyalahgunaan narkoba bagi siswa. Prayitno \& Amti (2004) mengemukakan bahwa layanan informasi yang diberikan oleh konselor kepada konseli dimaksudkan untuk memberikan pemahaman kepada individu yang berkepentingan tentang berbagai hal yang diperlukan untuk menjalani tugas atau kegiatan, atau untuk menentukan arah suatu tujuan atau rencana yang dikehendaki. Layanan informasi berupaya untuk memenuhi kebutuhan individu akan informasi yang diperlukan. Melalui layanan informasi akan disampaikan berbagai informasi yang dibutuhkan oleh individu sebagai peserta layanan yang kemudian informasi tersebut nantinya dapat diolah dan dipergunakan untuk kepentingan kehidupan dan juga kemampuan positif individu yang bersangkutan (Fitriyanti et al., 2017)

Berdasarkan pendapat di atas, maka dapat disimpulkan bahwa layanan informasi adalah sebuah teknik layanan yang ada di dalam BK yang dalam praktiknya diyakini mampu memberikan pemahaman dari berbagai informasi yang nantinya akan berguna bagi konseli dalam proses pengambilan keputusan saat berusaha memecahkan permasalahan yang dihadapinya.

Diketahui bahwa individu kategori remaja menjadi penyumbang terbanyak kasus penyalahgunaan narkoba. Namun patut disyukuri bahwa, di SMK Trisastra 1 Jakarta belum terdapat kasus penyalahgunaan narkoba yang dilakukan oleh siswa. Agar hal positif ini tetap terjaga, maka diperlukan pencegahan oleh guru BK dengan memberikan sebuah layanan informasi kepada siswa guna memberikan pemahaman terhadap penyalahgunaan narkoba. Melalui penelitian ini akan diuji apakah layanan informasi memiliki pengaruh terhadap pemahaman penyalahgunaan narkoba. Tujuan penelitian ini adalah untuk mengetahui apakah layanan informasi memiliki pengaruh terhadap pemahaman penyalahgunaan narkoba pada siswa kelas X SMK Trisastra 1 Jakarta. Hipotesis pada penelitian ini adalah layanan informasi mampu meningkatkan pemahaman penyalahgunaan narkoba pada siswa kelas X SMK Trisastra 1 Jakarta. 


\section{Metode}

Penelitian ini dilakukan di SMK Trisastra 1 Jakarta di Jalan Lubang Buaya, Cipayung, Jakarta Timur. Penelitian ini dilakukan sejak Maret hingga Agustus 2021. Metode yang digunakan dalam penelitian ini adalah metode kuantitatif dengan pendekatan eksperimen. Dalam penelitian ini diterapkan metode one group pre-test posttest design. Desain ini merupakan kegiatan penelitian yang memberikan tes awal (pretest) sebelum diberikan perlakuan, selanjutnya setelah diberikan perlakuan barulah memberikan tes akhir (posttest) (Yusuf, 2014). Dalam penjelasan tersebut, dapat dikatakan perlakuan diberikan kepada kelompok yang akan diteliti atau diberikan eksperimen. Populasi dalam penelitian ini adalah seluruh siswa kelas X SMK Trisastra 1 Jakarta yang berjumlah 60 siswa. Sampel ditarik dengan melakukan simple random sampling dan menghasilkan 38 siswa sebagai objek penelitian.

\section{Hasil dan Diskusi}

Berikut disajikan hasil pelaksanaan pretest pada penelitian ini.

Tabel 1. Frekuensi tingkat pemahaman bahaya penyalahgunaan narkoba dalam kegiatan pretest

\begin{tabular}{ccc}
\hline Interval & Kategori & Frekuensi \\
\hline $81 \%-100 \%$ & Sangat Tinggi & 0 \\
\hline $61 \%-80 \%$ & Tinggi & 5 \\
\hline $41 \%-60 \%$ & Sedang & 27 \\
\hline $21 \%-40 \%$ & Rendah & 6 \\
\hline $0 \%-20 \%$ & Sangat Rendah & 0 \\
\hline \multicolumn{2}{c}{ Sumber: Diolah dari hasil penelitian, 2021 }
\end{tabular}

Berdasarkan tabel 1 di atas dapat diketahui bahwa sebelum diberikan layanan informasi terdapat 27 siswa yang memiliki pemahaman bahaya penyalahgunaan narkoba pada kategori rendah dan sedang. Namun, terdapat lima siswa yang memiliki pemahaman bahaya penyalahgunaan narkoba yang termasuk dalam kategori tinggi. Hasil perhitungan pretest terhadap 38 siswa kelas X SMK Trisastra 1 Jakarta berdasarkan instrumen yang digunakan memberikan informasi bahwa pemahaman bahaya penyalahgunaan narkoba pada siswa berada dalam kategori yang sedang.

Hasil pretest selanjutnya diikuti dengan pemberian layanan informasi sebanyak enam kali pertemuan. Setelah pelaksanaan layanan informasi maka dilakukan posttest untuk mengetahui bagaimana efek yang diberikan layanan informasi bagi pemahaman bahaya penyalahgunaan narkoba pada siswa. Hasil pelaksanaan posttest disajikan pada tabel 2 berikut.

Tabel 2. Frekuensi tingkat pemahaman bahaya penyalahgunaan narkoba dalam kegiatan posttest

\begin{tabular}{ccc}
\hline Interval & Kategori & Frekuensi \\
\hline $81 \%-100 \%$ & Sangat Tinggi & 35 \\
\hline $61 \%-80 \%$ & Tinggi & 3 \\
\hline $41 \%-60 \%$ & Sedang & 0 \\
\hline $21 \%-40 \%$ & Rendah & 0 \\
\hline $0 \%-20 \%$ & Sangat Rendah & 0 \\
\hline \multicolumn{2}{c}{ Sumber: Diolah dari hasil penelitian, 2021}
\end{tabular}


Berdasarkan hasil kegiatan posttest diketahui bahwa tingkat pemahaman bahaya penyalahgunaan narkoba pada siswa mengalami peningkatan. Tabel distribusi frekuensi menggambarkan bahwa 38 siswa memiliki tingkat pemahaman bahaya penyalahgunaan narkoba yang tinggi setelah diberikan layanan informasi. Untuk mengetahui adanya perbedaan pemahaman bahaya penyalahgunaan narkoba pada siswa dalam kegiatan pretest dan posttest dapat dilihat pada tabel 3 berikut.

Tabel 3. Hasil Uji Paired Sample Statistics

\begin{tabular}{|c|c|c|c|c|c|}
\hline & \multicolumn{5}{|c|}{ Paired Samples Statistics } \\
\hline & & Mean & $\mathrm{N}$ & Std. Deviation & Std. Error Mean \\
\hline \multirow[t]{2}{*}{ Pair 1} & Pretest & 24.97 & 38 & 5.304 & .860 \\
\hline & Posttest & 48.42 & 38 & 3.576 & .580 \\
\hline
\end{tabular}

Berdasarkan tabel 3 pada kegiatan pretest diperoleh rata-rata sebesar 24,97 sedangkan untuk nilai posttest yakni sebesar 48,42. Jumlah sampel yang digunakan adalah sebanyak 38 siswa. Untuk nilai standar deviasi pada pretest sebesar 5,304 dan posttest sebesar 3,576. Terakhir adalah nilai std.error mean untuk pretest sebesar 0.860 dan untuk posttest sebesar 0,580, Karena bahaya penyalahgunaan narkoba pada pretest 24,97 < posttest 48,42 , maka itu artinya terdapat perbedaan antara pretest dengan hasil posttest. Untuk membuktikan bahwa perbedaan itu benarbenar signifikan atau tidak maka perlu ditafsirkan hasil uji paired sample test yang terdapat pada tabel 4 berikut.

Tabel 4. Hasil Uji Paired Samples Test

Paired Samples Test

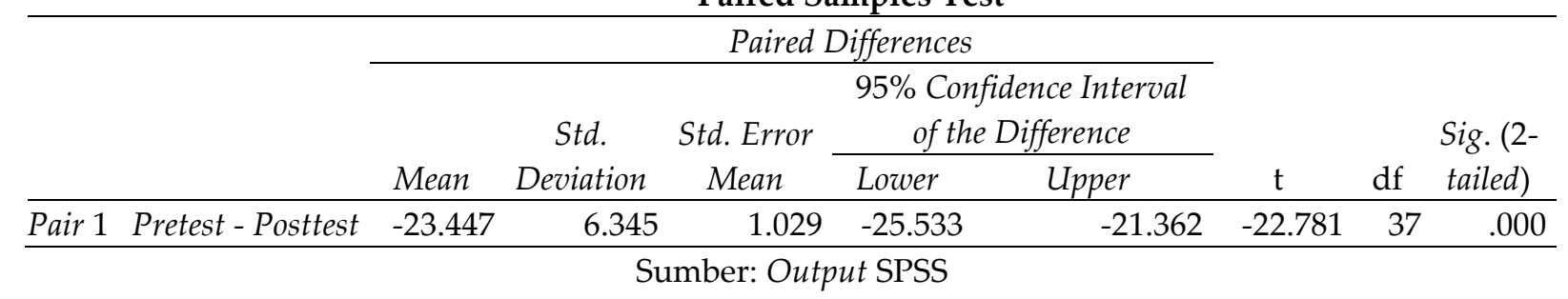

Dasar pengambilan keputusan pengujian hipotesis dalam paired sample t-test adalah dengan membandingkan antara nilai thitung dan tabel yakni sebagai berikut:

a. Jika nilai thitung $>t_{\text {tabel }}$ berarti hipotesis diterima.

b. Jika nilai $t_{\text {hitung }}<t_{\text {tabel }}$ yang berarti hipotesis ditolak.

Berdasarkan hasil dari paired sample t-test diketahui nilai $t$ adalah $-22,781$, nilai $d f$ adalah 37 dan nilai signifikansi $0.05 / 2$ sama dengan 0,025 dan diperoleh nilai $t_{\text {tabel }} 3.576$. Oleh karena nilai thitung 22,781 > ttabel 3.576 maka dapat dikatakan bahwa hipotesis yang berbunyi layanan informasi mampu meningkatkan pemahaman penyalahgunaan narkoba pada siswa kelas X SMK Trisastra 1 Jakarta dinyatakan diterima. Tujuan khusus layanan informasi terkait dengan fungsi-fungsi konseling salah satunya adalah fungsi pemahaman. Fungsi pemahaman paling dominan dan paling langsung diemban yaitu oleh layanan informasi. Siswa diharapkan mampu memahami informasi yang diberikan oleh guru BK. Penguasaan informasi tersebut dapat digunakan untuk pemecahan masalah, untuk mencegah timbulnya masalah, untuk mengembangkan dan memelihara potensi yang ada, dan untuk memungkinkan peserta yang bersangkutan membuka diri dalam mengaktualisasikan hak-haknya (Prayitno \& Amti, 2013). Sejalan dengan tujuan khusus layanan informasi tersebut, pemberian layanan informasi dalam penelitian ini dilakukan untuk memberikan pemahaman secara langsung kepada siswa tentang bahaya penyalahgunaan 
narkoba, siswa memahami apa yangdibahas dalam layanan, dan sebagai pencegahan timbulnya masalah baru yaitu penyalahgunaan narkoba pada siswa. Selain itu, diharapkan pula pemberian layanan informasi ini meminimalisir munculnya keinginan yang ada di dalam diri siswa untuk mencoba mengonsumsi narkoba setelah memahami bahaya yang ditimbulkan karena penyalahgunaan narkoba.

Setelah mengikuti layanan informasi, pemahaman siswa tentang bahaya penyalahgunaan narkoba menurut hasil analisis posttest menunjukkan rata-rata persentase sebesar $91 \%$ yang termasuk dalam kategori sangat tinggi. Berdasarkan hasil pretest dan posttest tersebut maka dapat diketahui bahwa terdapat pengaruh layanan informasi terhadap pemahaman siswa tentang penyalahgunaan narkoba yaitu bahaya yang ditimbulkan akibat penyalahgunaan narkoba. Hal ini dapat dilihat dari data yang menunjukkan pemahaman siswa sebelum diberikan atau mengikuti layanan informasi sebesar $49.50 \%$ dan sesudah diberikan layanan informasi meningkat menjadi $91.41 \%$.

Peningkatan pemahaman siswa tentang bahaya penyalahgunaan narkoba yang lebih spesifik ditunjukkan dari hasil perhitungan ujii beda dengan rumus $\mathrm{t}$ test yang menunjukkan thitung 22.781 dan $t_{\text {tabel }} 3.576$ jadi nilai thitung $>t_{\text {tabel. }}$. Hal ini menunjukkan bahwa adanya pengaruh pada pemahaman siswa tentang penyalahgunaan narkoba. Hasil penelitian menunjukkan ratarata pemahaman siswa tentang bahaya penyalahgunaan narkoba sesudah diberikan layanan informasi mengalami peningkataan dari sebelumnya. Dengan demikian layanan informasi yang diberikan kepada siswa kelas $X$ di SMK Trisastra 1 Jakarta dapat meningkatkan pemahaman tentang penyalahgunaan narkoba terkait dengan bahaya yang ditimbulkan dari penyalahgunaan narkoba.

Dalam penelitian yang dilakukan oleh Batubara \& Dwinata (2017) ditemukan pengaruh layanan informasi terhadap pemahaman siswa pada penyalahgunaan narkoba. Penelitian ini menggunakan metode penelitian kuantitatif dengan pendekatan eksperimen. Berdasarkan hasil penelitian dan pembahasan dapat disimpulkan bahwa, ada pengaruh layanan informasi dengan pemahaman siswa kelas X dan XI SMK Swasta Maju Binjai tahun pelajaran 2016/2017. Penelitian yang dilakukan oleh Wulandari (2017) dengan judul penelitian Pencegahan Penyalahgunaan Narkoba dengan Layanan Informasi oleh Guru Bimbingan dan Konseling di SMPN 3 Banjarbaru pun demikian. Metode penelitian yang digunakan dalam penelitian ini menggunakan metode deskriptif kualitatif. Berdasarkan hasil penelitian dan pembahasan dapat disimpulkan bahwa,:(1) layanan informasi diberikan dengan materi mengenai narkoba, jenis-jenis narkoba, akibat penyalahgunaan narkoba baik jangka pendek maupun jangka panjang serta pandangan narkoba dalam agama juga cara penolakan terhadap penawaran narkoba dengan materi tersebut siswa tidak hanya mengetahui tentang narkoba dan jenis-jenisnya namun juga mengetahui tentang cara penolakan terhadap situasi penawaran, (2) layanan informasi dengan metode menggunakan media lebih mempermudah siswa memahami materi dan siswa juga lebih antusias dalam megikuti layanan informasi dibandungkan dengan menggunakan metode ceramah dan diskusi dalam layanan informasi mengenai pencegahan penyalahgunaan narkoba di SMPN 3 Banjarbaru. Perbedaan penelitian di atas adalah menggunakan metode deskriptif kualitatif sedangkan peneliti menggunakan metode kuantitatif dengan pendekatan eksperimen.

Simangunsong (2015) dengan judul penelitian Penyalahgunaan Narkoba di Kalangan Remaja (Studi Kasus pada Badan Narkotika Nasional Kota Tanjungpinang), juga menemukan adanya faktor yang memengaruhi seseorang menyalahgunakan narkoba. Penelitian ini menggunakan metode kualitatif sedangkan dasar penelitian yang akan digunakan adalah studi kasus dan cara menganalisis data menggunakan deskriptif kualitatif. Berdasarkan hasil penelitian dapat disimpulkan bahwa secara garis besar faktor yang menyebabkan terjadinya 
penyalahgunaan narkoba di kalangan remaja terdiri dari faktor internal maupun faktor eksternal. Menurut hasil penelitian, faktor yang paling dominan yang menyebabkan terjadinya penyalahgunaan narkoba di kalangan remaja adalah disebabkan karena faktor pergaulan, dimana karena pergaulan yang terlalu bebas dan tidak terkontrol menyebabkan remaja hilang kendali sehingga mudah terpengaruh dengan mengonsumsi narkoba. Selain itu, kondisi kepribadian remaja yang tergolong masih labil sehingga remaja mudah terbujuk untuk menyalahgunakan narkoba tanpa memikirkan dampak buruk dari narkoba itu sendiri.

Implikasi yang dapat dipetik berdasarkan hasil penelitian ini adalah, guru BK selaku pelaksana kegiatan layanan Bimbingan dan Konseling diharapkan mampu melaksanakan layanan informasi dalam upaya preventif atau pencegahan terhadap penyalahgunaan narkoba. Hal ini dapat dilakukan dengan memberikan sebuah materi layanan mengenai bahaya yang akan ditimbulkan akibat penyalahgunaan narkoba.

\section{Simpulan}

Berdasarkan hasil dan diskusi, maka dapat ditarik kesimpulan bahwa layanan informasi mampu meningkatkan pemahaman bahaya penyalahgunaan narkoba. Melalui hasil penelitian ini maka diharapkan kepala sekolah mampu berkoordinasi dengan pihak terkait jika sekiranya terdapat siswa yang berpotensi menyalahgunakan narkoba. Selain itu guru BK diharapkan mampu terus-menerus memberikan langkah preventif kepada siswa agar siswa tidak dapat dengan mudah terpengaruh atas bujuk rayu oknum-oknum penyalah guna narkoba. Bagi peneliti yang ingin melanjutkan penelitian ini diharapkan mampu melanjutkan penelitian ini dengan menggunakan pendekatan penelitian dan pengambilan sampel yang berbeda.

\section{Ucapan Terima Kasih}

Penulis menyampaikan terima kasih kepada Allah SWT dan kepada semua pihak yang telah membantu dan mendukung penulis dalam menyelesaikan penelitian yang penulis rangkum dalam artikel ini. Rasa terima kasih yang begitu dalam penulis haturkan kepada seluruh pengurus SMK Trisastra 1 Jakarta yang telah memberikan izin dan dukungan kepada penuis atas penelitian yang dilakukan di sekolah tersebut.

\section{Daftar Rujukan}

Batubara, A., \& Dwinata, Y. (2017). Pengaruh layanan informasi terhadap pemahaman siswa pada penyalahgunaan narkoba di kelas X dan XI SMK Swasta Maju Binjai Tahun Pelajaran 2016/2017. Jurnal Serunai Bimbingan dan Konseling, 6(4), 51-61.

Fitriyanti, E., Dachmiati, S., \& Satrianta, H. (2017). Information services in counseling and locus of control toward communication between parents and children's. Teraputik: Jurnal Bimbingan Dan Konseling, 1(2), 125-131.

Rohman, A. F. (2019). Tinjauam Hukum Islam terhadap Surat Edaran Mahkamah Agung No. 7 Tahun 2009 tentang Menempatkan Pemakai Narkoba ke Dalam Panti Terapi dan Rehabilitasi (Studi Kasus di Pondok Pesantren Nurul Ichsan Purbalingga). https://dspace.uii.ac.id/bitstream/handle/123456789/17094/05.2\%20bab\%202.pdf? sequence $=6 \&$ isAllowed $=\mathrm{y}$.

Prayitno, \& Amti, E. (2013). Dasar-Dasar Bimbingan dan Konseling. PT. Rineka Cipta.

Simangunsong, J. (2015). Penyalahgunaan Narkoba Di Kalangan Remaja (Studi kasus pada Badan Narkotika Nasional Kota Tanjungpinang). Program Studi Ilmu Sosiologi Fakultas Ilmu Sosial 
142 Layanan informasi untuk meningkatkan pemahaman penyalahgunaan narkoba pada siswa

Dan Politik Universitas Maritim Raja Ali Haji Tanjungpinang. (E-journal).

Undang-Undang Nomor 35 Tahun 2009 tentang Narkotika.

Wulandari, W. (2017). Pencegahan Penyalahgunaan Narkoba dengan Layanan Informasi oleh

Guru Bimbingan dan Konseling Di SMPN 3 Banjarbaru. Jurnal Mahasiswa BK An-Nur: Berbeda, Bermakna, Mulia, 3(2), 25-31.

Yusuf, A. M. (2014). Metode Penelitian: Kuantitatif, Kualitatif, dan Penelitian Gabungan. Kencana Prenadamedia Group.

\section{Competing interests:}

The authors declare that they have no significant competing financial, professional or personal interests that might have influenced the performance or presentation of the work described in this manuscript. 